\title{
Cross-sectional Study of Perceived Stress among Special Education Teachers
}

\author{
Michael Eskay ${ }^{1} \&$ Bartholomew Chinweuba Nwefuru ${ }^{1}$ \\ ${ }^{1}$ Department of Educational Foundations, University of Nigeria, Nsukka, Enugu State, Nigeria \\ Correspondence: Bartholomew Chinweuba Nwefuru, Department of Educational Foundations, University of \\ Nigeria, Nsukka. E-mail: nwefurubc@ gmail.com
}

Received: October 5, 2019 Accepted: December 2, 2019 Online Published: December 12, 2019

doi:10.5539/gjhs.v11n14p123 URL: https://doi.org/10.5539/gjhs.v11n14p123

\begin{abstract}
This research investigated perceived stress among special education teachers in Nigeria. A cross-sectional research design was adopted. The study covered all public, private and special schools with special educators in South-East Nigeria. The study respondents were a convenience sample of 243 special education teachers. The instrument for data collection was a questionnaire titled "Perceived Stress Questionnaire" (PSQ). The instrument was administered with the assistance of five research aids. Mean and standard deviation was used in answering the research question while t-test was used on hypothesis. Results showed that there is a significant difference between the mean ratings of male and female special education teachers in perceived stress Male special education teachers feels less stressed than their female counterparts. There is a need for governmental and mental health specialists to assist special education teachers with respect to stress management.
\end{abstract}

Keywords: gender, perceived stress, special education and teachers

\section{Introduction}

Special education is the kind of education that is designed to meet the learning needs of individuals with disabilities. According to UNESCO (2003), the basic role of special education teachers is to teach children with special educational needs regardless of differences and difficulties they are having. Ainscow and Haile-Giorgis (1998) added that special education teacher offers instructions directed to meet personalized needs, and equalizing education to all students that would have been limited access to education. More so, the special needs children covers a long scope which includes sightedness, hearing, mental problems, social maladjustment among others resulting from birth circumstance, or inheritance, life accident. In directing teachers on how best to adjust and offer necessary assistance to special need learners, Nigeria's National Policy on Education (2004) outlined aims of special education to include: offering in-depth meaning to the notion of making education available to all individual regardless of physical challenges, providing efficient education to every child with special needs to enable them contribute meaningfully to the industrialization of their environs and making curriculum that will accommodate every child. Accordingly, Adebisi and Onye (2013) were of the view that special education teachers oversee activities and interactions of people with emotional, mental, and limb deformation issues among others. Buttressing further, the authors observed that teachers of special education could be triggered off with responsibilities that they cannot offer to individuals with special needs because of limited resources from the government. This seems to be one of the reasons why teachers of special education may encounter stress.

Stress is one of the chiefly global health issues that disturb an individual's homeostasis irrespective of age, class and status. Stress is an individual's psychological, mental and physiological behavioural reflection to any demand made on the body. Stress according to D'Arcy (2007) is the body's means of responding to demand placed on the body and in getting ready to surmount life difficult situation. It is assumed that when stress turnout good, teachers and other individuals will be glad about their respective careers and professions but when it turns out bad the opposite will occur hence the need to understand the place of stress among special education teachers regardless of gender difference and how it can be ameliorated for better outcome among teachers. WHO (2002) was of the view that a good kind of stress can positively transform an individual's mind and inform the individual that they cope well in a given situation. Stress sometimes can be helpful to an individual's life as it can assist one to escape a dangerous situation. For D'Arcy (2007), stress can be a good thing, but an overload of it leads to negative outcomes. Stress overload is as a result of overreaction or inability to readjust properly, as it can provide the channels to 
showcase talents and energizes one's spirit to go after happiness. Although, it can cause illness and exhaustion once it is the negative form of stress. The essential factor to remember about stress is that certain forms are normal and vital to one's body as our bodies are poised to either run away from the stressor or stick around and fight against it. Therefore, teachers of education and special education, in particular, should embrace their environmental demands in good fate to enable them to perform expectedly in undertaking their day-to-day responsibility of teaching and instructing learners.

Furthermore, stress has been grouped into three: acute stress, episodic acute stress and chronic stress (American Psychological Association, [APA], 2012). APA stated that each of the stress types has its feature, body duration, symptoms and treatment pattern. Acute stress results from pressing demands of closely past and anticipated demands and pressures of the near future with emotional distress and muscular problems among other symptoms. Acute stress cause trembling hands, increase heart rate and blood pressure of an individual (Hillman, 2018). Acute stress can crop up in anyone's life even when it is manageable and treatable. According to Legg (2016), all three forms of stress are manageable and treatable depending on when and how one handles it. This implies that educational teachers and teachers of special education, in particular, may experience stress and may need also to be aware that stress seems to be unavoidable in the teaching profession. This is so because evidence has shown that teacher experience stress at a different stage of their professional role.

Griffith, Steptoe and Cropley (1999) noted that the teaching profession is very stressful. Forman (1994) was of the view that tasks surrounding the teaching profession make teachers be stressed. Travers and Cooper (1993) noted that teachers find their profession to very tasking than other professions. Accordingly, Smith, Brice, Collins, Matthews, and McNamara (2000) reported that teachers nowadays are being recorded with a high percentage of job stress than those at medical and related professions. The scholars further added that teachers record absenteeism from the workplace, less satisfaction with work and some health problems when encountering job stress. Accordingly, Kyriacou and Sutcliffe (1978) saw teacher stress as encompassing of negative affects like depressive behavior or anger which is usually accompanied by potentially harmful emotional changes like heart rate increase. Kyriacou (2001) defined teacher stress as frustration, depression, anger, nervous and anxiety and other unpleasant related emotions that teachers experience in their effort to do their job. The author further noted that teachers became stressed because of workload, environment, and students' lack of motivation among others.

Also, it seems like limited facilities around the school environment, poor working conditions, class period among others stimulates the level of stress teachers tend to perceive in their workplace. Kyriacou (2001) reported that the teacher's major source of stress includes indiscipline among students, lack of learning interest of students, workload demand, time pressures, exposure to evaluation by others, conflicts with administration and school management, lack of school equipment and poor working conditions. The main sources of stress experienced by a particular teacher will be unique to him or her because it will depend on the complex interaction between personality traits, values, skills, and circumstances (Montgomery \& Rupp, 2005). According to Suzić and Graonić (2009) other stressors in teachers' work include balancing private and work roles, lack of support from colleagues, strained interpersonal relationships, supervisor evaluation, discomfort in dealing with students' parents, student misbehaviour, and unsatisfactory management style. Adetayo, Ajani, and Olabisi (2014) revealed that worker's performance was affected by tiredness, worry, unhappiness, weakness, headache and anger. It was, therefore, indicated that work stress has a significant effect on employee's performance. Oghenetega (2014) revealed that there is a significant difference between the level of job stress in Federal, State and Private higher institutions in Nigeria. However, Ijadunola, Onayade, andAbiona (2003) reported that between 38\% and $40 \%$ of the workers sampled worked under unacceptable environmental conditions that were responsible for a decline in their work efficiency. The rate at which teachers perceive stress may differ by gender.

Gender according to Bravo (2000) is the range of characteristics pertaining to and differentiating between masculinity and femininity. In consonance with the above assertion, Cassel (2002) maintained that gender is the social fact of being male or female or having the recognizable traits of one's sex. Similarly, according to Okeke (2004), gender is a broad analytical concept, which draws out women role and responsibilities in relation to those of men. The author also referred to gender as a socially and culturally constructed characteristics and roles which are ascribed to male and female. The characteristics and behaviours that are generally associated with being a male are referred to as masculine and those associated with being a female are referred to as feminine. The author noted that an individual's stress can vary when measured based on gender difference. This implies that teachers especially those in special education experience stress in a different dimension. Though, the stand of scholars is not yet clear whether special education teachers experience stress. It is also not certain whether male and female special education teachers perceive stress in different ways. The purpose of this study was to ascertain gender differences in perceived stress among special education teachers in South-East Nigeria. 


\subsection{Research Question}

A research question was raised to guide the study

1) Does gender difference exist in perceived stress among special education teachers?

\subsection{Hypothesis}

The hypothesis below was raised and tested at 0.05 probability level.

1) There is no significant difference between the mean ratings of male and female special education teachers in perceived stress.

\section{Research Method}

A cross-sectional research design was adopted. The study covered all public, private and special schools with special educators in South-East Nigeria. The study respondents were a convenience sample of 243 special education teachers. The respondents provided informed consent in writing before participating in the study. The instrument for data collection was a self-report questionnaire titled "Perceived Stress Questionnaire" (PSQ). The PSQ was structured on a four-point rating scale of Strongly Agreed (SA) $=4$ points, Agreed $(A)=3$ points, Disagreed $(D)=2$ points and Strongly Disagreed $(\mathrm{SD})=1$ point. The instrument was face- validated by three stress management specialists. The internal consistency estimate of the PSQ was determined through Cronbach alpha $(\alpha=0.80)$. The instrument was administered with the assistance of five research aids. Mean and standard deviation was used in answering the research question while t-test was used to test the hypothesis.

\section{Results and Discussion}

Research Question: Does gender difference exist in perceived stress among special education teachers?

Table 1. Mean difference in perceived stress based on gender

\begin{tabular}{lccc}
\hline Teachers' Gender & N & Mean & Std. Deviation \\
\hline Male & 110 & 25.22 & 6.24 \\
Female & 133 & 28.13 & 5.09 \\
\hline
\end{tabular}

Result in Table 1 revealed that male special education teachers had mean stress of 25.22 with a standard deviation of 6.24 while female special education teachers had mean stress of 28.13 with a standard deviation of 6.09 .

\section{Hypothesis}

There is no significant difference between the mean ratings of male and female special education teachers in perceived stress.

Table 2. Independent samples test of mean difference in stress by gender

\begin{tabular}{cccccccc}
\hline Gender & $\mathbf{N}$ & $\mathbf{M} \pm \mathbf{S D}$ & $\mathbf{t}$ & $\mathbf{d f}$ & Sig. & Mean Difference & $\mathbf{9 5 \%} \mathbf{C I}$ \\
\hline Male & 110 & $25.22 \pm 6.24$ & & & & & \\
Female & 133 & $28.13 \pm 6.09$ & -3.66 & 241 & .000 & -2.909 & $-4.473,-1.346$ \\
\hline
\end{tabular}

$\mathrm{M} \pm \mathrm{SD}=$ Mean, Standard Deviation; $\mathrm{N}=$ Number of Respondents, $\mathrm{CI}=$ Confidence Interval.

Result in Table 2 showed that there is a significant difference between the mean ratings of male and female special education teachers in perceived stress, $\mathrm{t}(241)=-3.66, p=.000,95 \% \mathrm{CI}=-4.473,-1.346$. Therefore, the null hypothesis was rejected.

The current study found that there is a significant difference between the mean ratings of male and female special education teachers in perceived stress. Nnabuihe, Onyeizugbe, and Onwuka (2012) reported that stress is likely to be profound among female lecturers than their male counterparts. However, the finding disagrees with the opinion of Liu and Zhu (2009) that men are likely to experience more stress than women. Leka, Griffiths, and Cox (2003) reported that workplace stress is common among employees. Krnjajić (2003) reported that teachers stress is a resultant of work demand. Prakke, van Peet, and van der Wolf (2007) revealed that teachers of all institutions of learning encounter one form of stress or another from time to time as they try to adjust with school workload. 
Smith, Brice, Collins, Matthews, and McNamara (2000) revealed that those within the teaching profession also rate the profession as a stressful one. Also, Bermejo-Toro and Prieto-Ursua (2006) reported that teachers are stimulated for stress since the teaching profession is tasking and job-demanding. Kılınç, Cemaloğlu, and Savaş (2015) also reported that teachers experience stress in the teaching profession in their attempt to cope with their professional demands. Işıkhan (2004) reported that teachers experience stress because the profession of teaching is a stressful one. Klassen (2010) revealed that teachers experience much stress in the school.

\section{Conclusion}

It is concluded that there is a significant difference between the mean ratings of male and female special education teachers in perceived stress Male special education teachers feel less stressed than their female counterparts. There is a need for government agencies and mental health specialists to help special education teachers to manage stress.

\section{References}

Adetayo, J. O., Ajani, J. O. \& Olabisi, O. (2014). An Overview of the Effects of Job Stress on Employees Performance in Nigeria Tertiary Hospitals. Ekonomika, 60(4), 139-153.

Akinpelu, F. O. (1999). Roles of supportive services for the deaf in tertiary institutions. Journal of Nigerian Association of Specialists in Management of Hearing Impairment, 1(2), 41-50.

American Psychological Association. (2012). Stress: The different kinds of stress. Retrieved from http://www.apa.org/helcenter/stress-kind.aspx

Bermejo-Toro, L., \& Prieto-Ursua, M. (2006). Teachers' irrational beliefs and their relationship to distress in the profession. Psychology in Spain, 10, 88-96.

Bravo, B. (2000). Gender Mainstreaming and Implementation Framework. Baseline Definitions of key concepts and terms. $\quad$ Retrieved on $12^{\text {th }}$ June, 2000 from http://www.org/new/fileadmin/MULTIMEDIA/HQ/BSP/GENDER/PDF/1.\%20Baseline\%20Definitions\%O key:20gender-related\%20concepts.pdf

Cassell, E. (2000). Gender: Sexuality. Chicago: The world book Inc.

D’Arcy, L. (2007). Stress. Retrieved May 10, 2010 from http://www.kidshealth.org

Federal Republic of Nigeria. (2013). National Policy on Education. Lagos: NERDC Press.

Forman, S. G. (1994). Teacher stress management. In M. E. Bernard, \& R. DiGiuseppe (Eds.), Rational-emotive consultation in applied settings (pp. 107-128). Hillsdale, NJ: Lawrence Erlbaum Associates.

Hillman, K. (2018). An introduction to the different types of stress. Retrieved from https://www.healthguidance.org/entry/19191/1/an-introduction-to-the-different-types-of-stress.html

Ijadunola, K. T., Ijadunola, M. Y., Onayade, A. A., \& Abiona, T. C. (2003). Perceptions of Occupational Health Hazards Among Office Workers at the Obafemi Awolowo University, Ile-Ife. Nigerian Journal of Medicine, 12(3), 134-139.

Işıkhan, V. (2004). Çalışmahayatındastresvebaşaçıkmayolları [Ways of coping with stress at work]. Ankara: Sandal.

Kılınç, A. Ç., Cemaloğlu, N., \& Savaş, G. (2015). The relationship between teacher leadership, teacher professionalism, and perceived stress. Eurasian Journal of Educational Research, 58, 1-26. https://doi.org/10.14689/ejer.2015.58.5

Klassen, R. M. (2010). Teacher stress: The mediating role of collective efficacy beliefs. The Journal of Educational Research, 103(5), 342-350. https://doi.org/10.1080/00220670903383069

Krnjajić, S. (2003). The teacher under stress. Zbornik Instituta za Pedagoska Istrazivanja, 35, 222-244. https://doi.org/10.2298/ZIPI0335222K

Kyriacou, C. (2001). Teacher stress: Directions for future research. Educational Review, 53(1), 27-35. https://doi.org/10.1080/00131910124115

Kyriacou, C., \& Sutcliffe, J. (1978). A model of teacher stress. Educational Studies, 4(1), 1-6. https://doi.org/10.1080/0305569780040101

Legg, T. J. (2016). What's your stress type? The headline editorial team. Retrieved from http://www.healthline.com/health/whats-your-stresstype\#Outlook5

Leka, S., Griffiths, A., \& Cox, T. (2003). Work organisation and stress. Geneva: World Health Organization. 
Montgomery, C., \& Rupp, A., (2005). A meta-analysis for exploring the diverse causes and effects of stress in teachers. Canadian Journal of Education, 28(3), 458-486. https://doi.org/10.2307/4126479

Ogehenetega, L. U., Oyenike, O. E., \& Ugeh, C. H. (2014). Comparative study of (networking) usage by undergraduates in two tertiary institutions of Nigeria. Journal of Research on Humanities \& Social Science, 4(15), 21-24.

Okeke, E. C. (2004). Gender Sensitivity in Class Interaction. European Journal of Education Studies, 3(20), 201.

Prakke, B., van Peet, A., \& van der Wolf, K. (2007). Challenging parents, teacher occupational stress and health in Dutch primary schools. International Journal about Parents in Education, 1, 36-44.

Smith, A., Brice, C., Collins, A., Matthews, V., \& McNamara, R. (2000). Scale of Occupational Stress: A Further Analysis of the Impact of Demographic Factors and Type of Job. Contract Research Report No. 311/200, London: HSE Books.

Suzić, N., \& Graonić, J. (2009). The syndrome of burning ambition in teaching profession. Pedagoška Stvarnost, 55, 813-826.

Travers, C. J., \& Cooper, C. L. (1993). Mental health, job satisfaction and occupational stress among UK teachers. Work \& Stress, 7(3), 203-219. https://doi.org/10.1080/02678379308257062

UNESCO. (2003). The Salamanca statement and framework for action on special needs education. World Conference on Special Needs Education: Access and Quality, Salamanca, Spain, 7th-10th, June.

WHO. (2002). World Health Report 2002: Reducing risks, promoting healthy lives. Geneva, World Health Organization.

\section{Copyrights}

Copyright for this article is retained by the author(s), with first publication rights granted to the journal.

This is an open-access article distributed under the terms and conditions of the Creative Commons Attribution license (http://creativecommons.org/licenses/by/4.0/). 